\title{
KAJIAN HUKUM TENTANG TANGGUNG JAWAB ADMINISTRASI RUMAH SAKIT TERHADAP KESELAMATAN DAN KESEHATAN KERJA DITINJAU DARI PERATURAN MENTERI KESEHATAN NOMOR 66 TAHUN 2016 TENTANG KESELAMATAN DAN KESEHATAN KERJA RUMAH SAKIT
}

\author{
Sinatra Gunawan \\ gundiuwgm@gmail.com \\ Alumni Fakultas Hukum Universitas Widya Gama Mahakam Samarinda dan dokter RSUD AWS \\ Samarinda
}

\begin{abstract}
Health and Safety of Hospital Work (K3RS) is the application of UUD 1945 chapter 27 verse (2) and Chapter $28 \mathrm{H}$ and Health Ministry's Regulation number 66 2016. K3 has existed since long time ago and its application has been less satisfactory as this was proven by UU number 11970 about Work Safety and UU number 442009 about Hospital. The application of K3RS is one of the actions taken to ensure and protect the safety and health of the human resources of the hospital, patients, nurses, visitors, and its environment as well as its physical condition. Health Ministry's Regulation Number 662016 specifically describes about K3RS but there is no clear and detail description on what the hospital's responsibilities are along with their consequences.

The problem studied is related to the administrative responsibilities of the hospital along with their consequences for not executing Health Ministry's Regulation Number 662016 in terms of K3RS. Method used for this law research is Normative Jurisdictive with referential and field study as the data collection technique. The writer did the research by looking for and collecting secondary data, compiled, described, and then analyzed in order to form a systematic, factual, and accurate description of the facts, characteristics or multi-phenomenon relationship studied. Data were analyzed qualitatively and the conclusion was drawn from there which later became the answer of the problem of this research.

From the findings of the research, it was proven that there wasn't optimum administrative responsibilities of the hospital and there were neither consequences addressed in written nor in person form in regards of why the K3RS was not implemented. The conclusion was drawn from this research was the administrative responsibilities of the hospital related to K3RS were not continuously applied and the written consequences form of the Health Ministry's Regulation was not strict.
\end{abstract}

Keywords: K3RS, Helth Ministry's Regulation, Responsibilities and Consequences.

\section{PEDAHULUAN}

Era globalisasi menuntut pelaksanaan Keselamatan dan Kesehatan Kerja di setiap tempat kerja termasuk di sektor kesehatan seperti rumah sakit. Rumah sakit merupakan tempat kerja yang unik dan kompleks untuk menyediakan pelayanan kesehatan bagi masyarakat. Semakin luas pelayanan kesehatan dan bangunan fisik serta fungsi rumah sakit tersebut, maka 
akan semakin kompleks peralatan dan fasilitas yang dibutuhkan. Kerumitan tersebut menyebabkan rumah sakit mempunyai potensi bahaya yang sangat besar, tidak hanya bagi pasien dan tenaga medis, tetapi juga pengunjung rumah sakit.

Pelaksanaan Keselamatan dan

Kesehatan Kerja adalah salah satu bentuk penyelenggaraan kegiatan untuk menciptakan tempat kerja yang aman, sehat, sehingga dapat mengurangi dan bebas dari kecelakaan kerja serta penyakit akibat kerja yang pada akhirnya dapat meningkatkan efisiensi dan produktifitas kerja. ${ }^{1}$ Hal ini harus diterapkan pula di rumah sakit.

Keselamatan dan Kesehatan Kerja Rumah Sakit yang selanjutnya disingkat K3RS, menurut Peraturan Menteri Kesehatan Republik Indonesia Nomor 66 Tahun 2016 tentang Keselamatan dan Kesehatan Kerja Rumah Sakit adalah: segala kegiatan untuk menjamin dan melindungi keselamatan dan kesehatan bagi sumber daya manusia rumah sakit, pasien, pendamping pasien, pengunjung, maupun lingkungan rumah sakit melalui upaya pencegahan kecelakan kerja dan penyakit akibat kerja di rumah sakit.

Pengaturan K3RS bertujuan untuk terselenggaranya keselamatan dan Kesehatan Kerja di Rumah Sakit secara optimal, efektif, efisien dan berkesinambungan.

Data berupa penelitian di Rumah Sakit Elim Rantepao dan Rumah Sakit Umum Daerah Lakipadada Makale Kabupaten Tana Toraja tahun 2008 mendapatkan 138 tenaga kerja Rumah Sakit

\footnotetext{
1 Liza Salawati, Hubungan Prilaku, Manajemen Keselamatan dan Kesehatan Kerja dengan Terjadinya Kecelakaan Kerja di Laboratorium Patologi Klinik Rumah Sakit Umum DR Zainoel Abidin Banda Aceh tahun 2009,Tesis, Universitas Sumatera Utara Medan, Medan, 2009, hlm. 3.
}

mengalami kecelakaan kerja seperti tertusuk jarum, dan teriris pisau. $^{2}$ Diperlukan publikasi data semacam ini setiap tahun dan setiap rumah sakit untuk mengetahui pelaksanaan keselamatan dan kesehatan kerja di rumah sakit.

Data Kementerian Tenaga Kerja dan Transmigrasi menyebutkan, sampai tahun 2013 di Indonesia tidak kurang dari enam pekerja meninggal dunia setiap hari akibat kecelakaan kerja. Angka tersebut tergolong tinggi dibandingkan negara Eropa hanya sebanyak dua orang meninggal dua per hari karena kecelakaan kerja. International Labour Organization (ILO) menyatakan setiap hari terjadi kecelakaan kerja yang mengakibatkan korban fatal kurang lebih 6000 kasus, sementara di Indonesia dari setiap 100.000 tenaga kerja terdapat 20 orang menderita kecelakaan kerja fatal dengan rata-rata per tahun terdapat 99.000 kasus kecelakaan kerja. Angka tersebut menginformasikan tingkat keparahan kecelakaan kerja di seluruh dunia pada umumnya dan di Indonesia pada khususnya yang masih cukup tinggi. ${ }^{3}$

Ditemukan data maupun dokumentasi tentang kurang optimal pelaksanaan K3RS yang menimbulkan kerugian fisik, psikis dan material; yang dapat dilihat pada media cetak dan media visual serta didengar pada media audio; yang mana tidak terekam dan tidak dipublikasi pada media publikasi ilmiah seperti dalam jurnal hukum, jurnal kesehatan, dan jurnal kedokteran, mengakibatkan tidak mengarahkan kepada

2 Martina Parubak, Studi Kecelakaan Kerja Pada Petugas RS Elim Rantepao dan RSUD Lakipadada Makale Kabupaten Tana Toraja, Artikel Dalam Jurnal Media Kesehatan Masyarakat Indonesia, Volume 5 Nomor 4, Oktober 2009, hlm. 83.

3 Soehatman Ramli, Sistem Manajemen Keselamatan dan Kesehatan Kerja OHSAS 18001, Dian Rakyat, Jakarta, 2010, hlm.1. 
tanggung jawab dan sanksi diberikan sehubungan K3RS.

Didalam praktek sehari-hari banyak orang yang tidak dapat membedakan antara pemerintahan yang dijalankan oleh pejabat pemerintah, dan administrasi yang dijalankan oleh administrasi. Hal ini disebabkan oleh karena pejabat pemerintah selalu merangkap sebagai administrator.

Kebijakan tentang keselamatan kerja di rumah sakit tertuang dalam UndangUndang Nomor 39 Tahun 2009, UndangUndang Nomor 44 Tahun 2009 dan Peraturan Menteri Kesehatan Nomor 66 Tahun 2016 yang merupakan amanat Undang-Undang Dasar 1945 Pasal 27 ayat (2) dan Pasal $28 \mathrm{H}$. Berdasarkan pada kebijakan tersebut maka semua rumah sakit harus tunduk pada kebijakan maupun aturan yang berlaku. Pelaksanaan keselamatan kerja dapat dilihat dari akreditasi rumah sakit.

Rumah Sakit harus menghormati hak pasien dalam memutuskan apa yang akan dia lakukan terhadap pasien. Alasannya adalah karena pada prinsipnya, perawatan yang akan dilakukannya, bukan terletak pada putusannya melainkan terletak pada kehendak pasien. Selain itu rumah sakit juga berkewajiban untuk mematuhi peraturan-peraturan organisatoris dan administratif, baik yang ditentukan oleh pemerintah melalui peraturan perundangundangan, maupun yang ditetapkan oleh organisasi profesi.

Ada perbedaan antara hukum publik dan privat bukanlah perbedaan yang prinsip, melainkan dilihat dari sifatnya itu sendiri. Hukum publik a priori memaksa, sedangkan hukum privat tidak, walaupun pada akhirnya memaksa juga. ${ }^{4}$

Sanksi merupakan inti dari penegakan hukum, dan biasanya diletakkan

4 Dudu Duswara Machmudin, Pengantar Ilmu Hukum Sebuah Sketsa, PT Refika Aditama, Bandung, 2013, hlm. 61. pada bagian akhir setiap peraturan. Sanksi administrasi dimaksudkan agar perbuatan pelanggaran itu dihentikan. Sifat sanksi adalah " reparatoir" artinya memulihkan pada keadaan semula. ${ }^{5}$ Pada Permenkes Nomor 66 Tahun 2016 tidak menerangkan secara jelas tentang sanksi. Sanksi bagi yang diberikan dijelaskan pula pada Pasal 11 ayat (2) dalam Undang-Undang Nomor 44 Tahun 2009 tentang Rumah Sakit Dalam Undang-Undang Nomor 44 Tahun 2009 Pasal 32q dijelaskan juga ada tuntutan maka tuntutan tersebut dapat perdata atau pidana, dan Pasal 46 menjelaskan tanggung jawab hukum Rumah Sakit terhadap kerugian yang ditimbulkan atas kelalaian.

Kesalahan rumah sakit dalam perawatan yang menimbulkan kerugian bagi pasien atau keluarganya, selain mengandung tanggung gugat perdata dan pertanggungjawaban pidana, juga mengandung pertanggungjawaban di bidang hukum administrasi. Hal ini dapat dilihat sebagaimana dinyatakan dalam Pasal 54 Ayat (1) UU No. 23 Tahun 1992 tentang Kesehatan, dan pada Pasal 29 ayat (4) Permenkes No 66 Tahun 2016 tentang K3RS, dan Pasal 29 ayat (2) UU No 44 Tahun 2009 tentang Rumah Sakit.

Tujuan hukuman administrasi yang dijatuhkan terhadap rumah sakit yang melakukan kesalahan, adalah untuk memperbaiki dan mendidik rumah sakit yang bersangkutan. Oleh karena itu, jika hukuman disiplin dalam bidang pelayanan kesehatan diterapkan, maka dengan sendirinya rasa tanggung jawab yang mendalam akan mendorong mereka untuk melakukan kewajiban profesi dan mematuhi ketentuan-ketentuan hukuman yang telah digariskan. Tiap orang dianggap mengetahui aturan hukum, sehingga

5 Philipus M. Hadjon, et al, Pengantar Hukum Administrasi Indonesia, Gadjah Mada University Press, Yogyakarta, 2015, hlm. 239. 
ketidaktahuan tentang Undang-Undang bukan merupakan suatu alasan. ${ }^{6}$

Pada masa sekarang hampir semua negara - negara di dunia menganut negara hukum yaitu menempatkan hukum sebagai aturan main penyelenggaraan kekuasaan negara dan pemerintahan. ${ }^{7}$ Indonesia juga menganut sebagai negara hukum. Sebagai negara hukum, maka tentu memiliki Hukum Administrasi Negara sebagai instrument untuk mengatur dan menyelenggarakan tugas-tugas pemerintahan negara serta mengatur hubungan antara pemerintah dan warga negara. Administrasi negara adalah gabungan jabatan-jabatan, alat administrasi yang dibawah pimpinan pemerintah melakukan sebagian pekerjaan pemerintah. ${ }^{8}$ Salah satu pekerjaan pemerintah adalah kesejahteraan rakyat. Keselamatan dan kesehatan kerja rumah sakit merupakan bagian dari kesejahteraan rakyat, oleh sebab rumah sakit perlu melaksanakan dengan mengikuti kaidah Hukum Administrasi Negara.

\section{RUMUSAN MASALAH}

Berdasarkan latar belakang yang telah dijelaskan maka dapat dirumuskan masalah penelitian sebagai berikut :

1. Bagaimana tanggung jawab administrasi rumah sakit terhadap keselamatan dan kesehatan kerja pegawai, pasien dan pengunjung rumah sakit?

2. Apa sanksi administrasi yang dapat diberikan kepada rumah sakit yang tidak melaksanakan Peraturan Menteri Kesehatan No 66 Tahun

6 Sudikno Mertokusumo, Mengenal Hukum Suatu Pengantar, Cahaya Atma Pustaka, Yogyakarta, 2016, hlm.115.

7 Ridwan HR, Hukum Administrasi Negara, Raja Grafindo Persada, Jakarta, 2011, hlm.24.

8 Ibid, hlm.29.
2016 tentang Keselamatan dan

Kesehatan Kerja Rumah Sakit?

\section{METODE PENELITIAN}

Jenis Penelitian yang dilakukan penulis adalah penelitian yuridis normatif. Penelitian dilakukan dengan metode pendekatan. Metode pendekatan yang digunakan adalah penelitian hukum normatif, yaitu penelitian yang dilakukan dengan cara meneliti bahan pustaka atau data sekunder dengan membaca dan menelaah literatur-literatur dan perundangundangan yang berkaitan dengan penelitian yang terdiri dari bahan hukum primer, bahan hukum sekunder, dan bahan hukum tersier.

Metode pendekatan ini adalah karena penelitian ini akan menelaah mengenai tanggung jawab administrasi rumah sakit dan sanksi yang diberikan kepada rumah sakit dihubungkan dengan peraturan kebijakan yang diterbitkan oleh menteri kesehatan nomor 66 tahun 2016 tentang keselamatan dan kesehatan kerja rumah sakit.

Penulis menjelaskan keadaan dari objek yang diteliti dan sejumlah faktorfaktor yang mempengaruhi data yang diperoleh, data tersebut itu dikumpulkan, disusun, dijelaskan, kemudian dianalisis. Penulis membuat deskripsi, gambaran atau lukisan secara sistematis, faktual, dan akurat mengenai fakta-fakta, sifat-sifat atau hubungan antar fenomena yang diselidiki. Laporan penelitian akan berisi kutipankutipan data untuk memberi gambaran penyajian laporan tersebut. Data tersebut dapat berasal dari cacatan lapangan, dokumen pribadi, catatan atau memo, berita media cetak atau media elektronik dan dokumen resmi lainnya. Peneliti menganalisis data tersebut dan diharapkan data dalam bentuk aslinya. 
Teknik atau metode pengumpulan data dalam penelitian ini adalah studi kepustakaan dan studi lapangan. Studi kepustakaan dan studi lapangan adalah upaya mencari dan mengumpulkan data sekunder, disusun, dijelaskan, kemudian dianalisis sehingga membuat deskripsi, gambaran atau lukisan secara sistematis, faktual, dan akurat mengenai fakta-fakta, sifat-sifat atau hubungan antar fenomena yang diselidiki. Studi lapangan dengan melakukan diskusi dan wawancara di Dinas Kesehatan Kota Samarinda dengan Kepala Dinas Kesehatan Kota beserta staf. Wawancara mengenai Tanggung Jawab Administrasi Rumah Sakit Terhadap Keselamatan dan Kesehatan Kerja di Tinjau dari PERMENKES Nomor 66 Tahun 2016 tentang Keselamatan dan Kesehatan Kerja Rumah Sakit.

Metode analisis pada penelitian ini adalah analisis data kualitatif, yaitu proses penyusunan, mengkategorikan data kualitatif, mencari pola atau tema dengan maksud memahami maknanya. Peneliti menganalisis data tersebut dan diharapkan data dalam bentuk aslinya. Pada penelitian ini, data terutama diperoleh dari bahan pustaka dimana pengolahan, analisis dan kontruksi datanya dilaksanakan dengan penelitian yang menggunakan metode kualitatif yang merupakan suatu cara penelitian yang menghasilkan data deskriptif serta komparatif. Dari hasil tersebut kemudian ditarik kesimpulan yang merupakan jawaban atas permasalahan yang diangkat dalam penelitian ini.

\section{PEMBAHASAN}

\section{A. Tanggung Jawab Administrasi Rumah Sakit Terhadap Keselamatan Dan Kesehatan Kerja Pegawai, Pasien Dan Pengunjung Rumah Sakit}

Sebelum melakukan pembahasan pada permasalahan yang ada, penulis membahas lebih dahulu tentang hal-hal dasar yang berkaitan terhadap permasalahan yang ada, dan diberikan perumpamaan terkait dengan keselamatan dan kesehatan kerja rumah sakit yang kemudian disingkat K3RS. Beberapa hal yang akan dijelaskan terlebih dahulu yaitu seperti bunyi Permenkes No 16 Tahun 2016, subjek hukum, objek hukum, perbuatan hukum, peristiwa hukum, akibat hukum, perbuatan melawan hukum, tanggung jawab, transaksi terapi, wewenang dan lain lain.

Pengertian Keselamatan Kerja, Kesehatan Kerja, Keselamatan dan Kesehatan Kerja Rumah Sakit dan Rumah Sakit menurut Peraturan Menteri Kesehatan Republik Indonesia Nomor 66 Tahun 2016 tentang Keselamatan dan Kesehatan Kerja Rumah Sakit sudah dijelaskan dilandasan teori dan factual. Penjelasan tersebut sudah memberikan fokus dan detail pelaksanaan K3RS sehingga pelaksanaan, tanggung jawab dan sanksi sehubungan K3RS tidak berbenturan dengan kegiatan lainnya dilevel administrasi negara.

Pelaksanaan K3RS tersurat dalam Permenkes No 66 Tahun 2016 Pasal 7 dan Pasal 8, sedangkan standar K3RS tersurat pada Pasal 11. Tehnis tindakan yang dilakukan sehubungan K3RS dicantumkan pada Pasal 14, Pasal 15, Pasal 16, Pasal 17, Pasal 18, Pasal 19. Dan sanksi yang diberikan dapat dilihat pada Pasal 29. Permenkes ini diundangkan di Jakarta tanggal 5 Januari 2017 dan berlaku paling lambat dalam jangka waktu 1(satu) tahun sejak Permenkes ini diundangkan.

Permasalahan yang dibahas dalam penelitian ini menunjukkan subjek hukum adalah pasien, keluarga pasien, pengunjung rumah sakit, karyawan rumah sakit, direktur rumah sakit, kepala dinas kesehatan, pemilik rumah sakit, bupati, walikota, dan 
gubernur. Sedangkan subyek hukum berupa badan hukum adalah rumah sakit. Subjek hukum seperti direktur rumah sakit atau kepala dinas kesehatan, secara umum yang menjadi pemangku hak dan kewajiban dengan tidak memandang agama atau kebudayaannya. Manusia sebagai pembawa hak oleh hukum diakui mendukung dan mempunyai hak dan kewajiban untuk melakukan tindakan hukum. Tindakan hukum dalam penelitian ini adalah pelaksanaan dan tidak melakukan pelaksaan K3RS. Rumah sakit, rumah bersalin dan sederajat merupakan subjek hukum lain berbadan hukum atau suatu perkumpulan atau lembaga yang dibuat oleh hukum dan mempunyai tujuan tertentu dengan syaratsyarat yang telah ditentukan oleh hukum.

Permasalahan yang dibahas dalam penelitian ini menunjukkan objek hukum adalah Permenkes No 66 Tahun 2016 tentang Keselamatan dan Kesehatan Kerja Rumah Sakit. Permenkes tersebut merupakan segala sesuatu yang menjadi acuan pengaturan hukum dimana segala hak dan kewajiban serta kekuasan subjek hukum seperti pasien, direktur, kepala dinas kesehatan dan lain lain terkaitan di dalamnya, hal ini dapat dilihat pada ketentuan umum, Pasal 12, Pasal 25. Dalam hukum administrasi negara yang menjadi objek hukum adalah keputusan tata usaha negara. Dan dalam hukum tata Negara objek hukumnya adalah kekuasaan ${ }^{9}$. Keputusan tata usaha negara dalam penelitian ini adalah Keputusan Menteri Kesehatan Nomor 66 Tahun 2016.

Permasalahan yang dibahas dalam penelitian ini menunjukkan akibat hukum yang timbul disebabkan tidak dilaksanakan K3RS sehingga terjadi sesuatu peristiwa tertentu. Peristiwa yang terjadi dapat memberikan akibat perbuatan hukum yang

\footnotetext{
${ }^{9}$ Muhamad Erwin, dan Firman Freaddy Busroh,Op.cit., hlm. 60.
}

merugikan subjek hukum, atau akibatakibat lain yang disebabkan karena kejadian-kejadian tertentu oleh perbuatan hukum $^{10}$. Akibat yang timbul dapat berupa kesakitan, kecacatan, perlamaan waktu kesakitan, kekuatiran dan meninggal.

Permasalahan yang dibahas dalam penelitian ini menunjukkan perbuatan hukum yang timbul oleh subjek hukum seperti tidak melaksanakan standar K3RS. Perbuatan hukum adalah segala perbuatan pimpinan atau direktur atau pemilik rumah sakit, kepala dinas kesehatan, dan gubernur yang tidak melaksakan atau melaksanakan Permenkes, yang secara sengaja atau tidak sengaja dilakukan oleh seseorang untuk menimbulkan hak-hak dan kewajiban.

Permasalahan yang dibahas dalam penelitian ini menunjukkan peristiwa hukum yang timbul oleh subjek hukum. Peristiwa hukum yang terjadi adalah semua kejadian atau fakta yang terjadi dalam kehidupan masyarakat yang mempunyai akibat hukum. Peristiwa hukum yang timbul pada permasalahan dalam tulisan ini adalah tidak melaksanakan permenkes atau undang - undang tentang K3 RS mengakibat kerugian material maupun immaterial terhadap subyek hukum. Peristiwa hukum dapat berupa banjir / kebakaran / tanah longsor yang terjadi di rumah sakit, pembuangan limbah berbahaya. Peristiwa lain pemberian obat yang tidak sesuai seperti tertukar, dosis yang berubah, dan obat palsu atau import, serta memperkerjakan karyawan yang tidak layak kerja karena gangguan pada fisik maupun mental.

Permasalahan yang dibahas dalam penelitian ini menunjukkan perbuatan melawan hukum dengan tidak melaksanakan Permenkes dan atau melaksanakan Permenkes dengan tidak optimal sehingga menimbulkan peristiwa 
hukum dan akibat hukum. Perbuatan melawan hukum lain dapat berupa pelaksanaan K3RS yang tidak mengikuti kaidah dan standar yang ditentukan. Akibat hukum dari suatu perbuatan yang bertentangan dengan hukum diatur juga oleh hukum, walaupun akibat itu memang tidak dikehendaki oleh yang melakukan perbuatan tersebut. Hal ini dapat berupa kelalaian atau kealphaan.

Meskipun azas legalitas mengandung kelemahan, tetap menjadi prinsip utama dalam setiap negara hukum. Azas legalitas merupakan dasar dalam penyelenggaraan kenegaraan dan pemerintahan. Dengan kata lain, setiap penyelenggaraan kenegaraan dan pemerintahan harus memiliki azas legitimasi, yaitu kewenangan yang diberikan oleh undang-undang. Substansi azas legalitas adalah wewenang. ${ }^{11}$ Dalam tulisan ini yang mempunyai wewenang mengatur K3 RS adalah Gubernur, Walikota, Bupati, Direktur RS, Kepala Dinas Kesehatan, Kepala Instalasi K3 dan struktur organisasi yang berhubungan dengan K3 RS.

Pengertian wewenang dalam bahasa hukum tidak sama dengan kekuasaan (macht). Kekuasaan hanya menggambarkan hak untuk berbuat atau tidak berbuat. Dalam hukum, wewenang sekaligus berarti hak dan kewajiban (rechten enplichten). Dalam kaitan dengan otonomi daerah, hak mengandung pengertian kekuasaan untuk mengatur sendiri (zelfregelen) dan mengelola sendiri (zelfbesturen), sedangkan kewajiban secara horizontal berarti kekuasaan untuk menyelenggarakan pemerintahan sebagaimana mestinya. Vertikal berarti kekuasaan untuk menjalankan pemerintahan dalam satu tertib ikatan pemerintahan secara keseluruhan. ${ }^{9}$ Dalam tulisan ini para aparatur negara yang terkait dengan K3RS

${ }^{11}$ Ridwan HR, Op.cit., hlm. 98. dan para pimpinan RS Swasta yang terkait K3RS mempunyai wewenang menjalankan K3RS sebagai kewajiban atau mempunyai kekuasaan untuk menyelenggarakan K3RS yang telah diamanahkan UU dan Kepmenkes.

Dalam kerangka negara hukum wewenang pemerintah berasal dari peraturan perundang-undangan yang berlaku. Dengan kata lain kewenangan hanya diberikan oleh UU di mana pembuat UU dapat memberikan wewenang pemerintah, baik kepada organ pemerintah maupun kepada aparatur pemerintahan. Peraturan perundang-undang yang ada dapat berupa UU tentang RS dan Permenkes tentang K3 RS.

Wewenang yang diberikan kepada Gubernur, Walikota, Bupati, Direktur RS berupa atribusi. Hal tersebut sesuai dengan teori administrasi negara yaitu salah satu kekuasaan yang diberikan oleh UU kepada pemerintah adalah atribusi. Pemberian wewenang pemerintah berupa amanah undang-undang dan turunannya berupa permenkes yang menjelaskan perlu pelaksanaan K3 RS.

Wewenang selanjutnya berupa delegasi yaitu penyerahan wewenang dari pejabat yang lebih tinggi kepada yang lebih rendah. Hal ini berupa surat keputusan direktur kepada kepala instalasi K3 RS atau komite K3 RS atau yang lainya yang memperhatikan K3RS.

Wewenang terakhir berupa mandat yaitu wewenang yang didapat melalui atribusi dan delegasi bisa dimandatkan kepada badan atau pegawai bawahan jika pejabat yang memperoleh wewenang itu tidak sanggup untuk melakukan sendiri . Berbeda dengan delegasi, mengenai mandat, pemberi mandat tetap berwenang untuk melakukan sendiri wewenangnya apabila ia menginginkan, dan memberi petunjuk kepada mandataris tentang apa yang diinginkannya. Dalam hal ini Kepala 
Instalasi K3 atau Kepala Komite K3 RS memberi mandat kepada staf $\mathrm{K} 3$ atau karyawan RS dalam pelaksanaan K3 yang mana tanggung jawab secara yuridis tetap pada kepala instalasi atau kepala komite.

Transaksi terapeutik adalah perjanjian antara dokter dengan pasien, perjanjian antara rumah sakit dengan pasien, keluarga pasien, dan pengunjung pasien yang datang dengan membayar karcis dan registrasi rumah sakit. Hal ini berupa hubungan hukum yang melahirkan hak dan kewajiban bagi kedua belah pihak. ${ }^{12}$ Berbeda dengan transaksi yang biasa dilakukan oleh masyarakat, transaksi terapeutik memiliki sifat atau ciri yang khusus yang berbeda dengan perjanjian pada umumnya dan ciri pada umumnya sesuai dengan kejadian yang terdapat di rumah sakit; kekhususannya terletak pada atau mengenai objek yang diperjanjikan. Objek dari perjanjian khusus ini adalah berupa upaya atau terapi untuk penyembuhan pasien. Jadi perjanjian atau transaksi terapeutik yang khusus, adalah suatu transaksi untuk menentukan atau upaya mencari terapi yang paling tepat bagi pasien yang dilakukan oleh dokter. Jadi menurut hukum, objek perjanjian dalam transaksi terapeutik bukan kesembuhan pasien, melainkan mencari upaya yang tepat untuk kesembuhan pasien. Sedangkan yang transaksi terapeutik yang umum yaitu tentang keselamatan dan kesehatan kerja di rumah sakit.

Persoalannya, apakah dalam perjanjian terapeutik juga berlaku ketentuan-ketentuan umum dari hukum perikatan sebagaimana yang diatur di dalam Buku III Kitab Undang-Undang Hukum Perdata? Hal ini dapat ditemukan bila akibat hukum yang timbul sehubungan dengan K3RS. Jadi, secara umum apa yang diatur dalam perjanjian menurut Buku

\footnotetext{
12 Bahder Johan Nasution, Op.cit., hlm. 11.
}

Kitab Undang-Undang Hukum Perdata, diatur juga atau berlaku pula dalam perjanjian terapeutik.

Pengajuan gugatan terhadap rumahsakit, dokter, atau tenaga kesehatan dan atau tenaga lainnya dengan alasan berdasarkan perbuatan melanggar hukum harus dipenuhi empat unsur. Hal ini juga dituangkan dalam buku Hukum Kesehatan Pertanggungjawaban Dokter karangan Bahder Johan Nasution yaitu:

a. Adanya pemberian gaji atau honor tetap yang dibayar secara periodik kepada dokter atau tenaga kesehatan yang bersangkutan.

b. Majikan atau dokter mempunyai wewenang untuk memberikan instruksi yang harus ditaati oleh bawahannya.

c. Adanya wewenang untuk mengadakan pengawasan.

d. Ada kesalahan atau kelalaian yang diperbuat oleh dokter atau tenaga kesehatan lainnya, di mana kesalahan atau kelalaian tersebut menimbulkan kerugian bagi pasien. ${ }^{13}$

Keempat unsur diatas telah dipenuhi sehingga gugatan dapat dilakukan, gugatan dapat berupa gugatan administrative, pidana, maupun perdata. Gugatan administratif sesuai dengan kedisplinan pegawai yang terdapat pada peraturan pemerintah, peraturan aparatur negara dan peraturan kementerian kesehatan.

Aspek negatif dari bentuk tanggung gugat dalam pelayanan kesehatan, adalah karena pasien mengalami kesulitan membuktikannya. Pada umumnya pasien tidak bisa membuktikan bahwa apa yang dideritanya, merupakan akibat dari kesalahan dan atau kelalaian dokter dalam perawatan atau dalam pelayanan kesehatan. Kesulitan dalam pembuktian ini karena 
pasien tidak memiliki pengetahuan yang cukup mengenai "patient safety" yang dialaminya atau yang dilakukan kepadanya.

Hubungan antara rumah sakit dengan pasien yang lahir dari transaksi terapeutik, selain menyangkut aspek hukum administraitf, hukum perdata juga menyangkut aspek hukum pidana. Aspek pidana baru timbul apabila dari pelayanan kesehatan yang dilakukan, berakibat atau menyebabkan pasien mati atau menderita cacat sebagaimana diatur dalam ketentuan Pasal 359, 360, dan 361 Kitab UndangUndang Hukum Pidana (KUHP). Apabila hal ini terjadi maka sanksinya bukan hanya suatu ganti rugi yang berupa materi, akan tetapi juga dapat merupakan hukuman badan sebagaimana diatur dalam Pasal 10 KUHP.

Dasar untuk mempermasalahkan aspek pidananya, berawal dari hubungan keperdataan yang timbul antara dokter dengan pasien, yaitu berupa transaksi terapeutik sebagai upaya penyembuhan. Aspek perdata dapat diawali dari tidak ada evaluasi dan monitoring K3RS berkesinambungan akibat lemah dalam pengawasan K3RS oleh subyek hukum.

Permenkes No 66 Tahun 2016 menjelaskan tentang sanksi pada Pasal 29 ayat (4). Sanksi yang diberikan berupa teguran lisan atau teguran tertulis kepada Rumah Sakit yang tidak menyelenggarakan K3RS. Sanksi tersebut berupa sanksi administratif.

Permenkes tersebut tidak terlepas dari Undang-Undang Nomor 44 Tahun 2009 Tentang Rumah Sakit yang dapat dilihat pada lampiran permenkes tersebut. Sanksi yang diberikan pada rumah sakit dapat mengacu pada aturan perundangan tersebut. Dalam UU No 44 Tahun 2009 ada bunyi tentang sanksi perdata dan pidana.

Menurut analisa penulis setelah melakukan penjabaran hal-hal diatas adalah:
Terbitnya Peraturan Menteri Kesehatan Nomor 66 Tahun 2016 Tentang Keselamatan dan Kesehatan Kerja di Rumah Sakit merupakan turunan dari Undang Undang Nomor 36 Tahun 2009 tentang Kesehatan Pasal 6, Pasal 10, Pasal 15; Undang Undang Nomor 44 Tahun 2009 tentang Rumah Sakit Pasal 2, Pasal 11 ayat (2); dan merupakan amanah UndangUndang Dasar 1945 Pasal 27 ayat (2), 28H;

Tanggung jawab administrasi rumah sakit berupa pelaksanaan K3RS adalah sesuai arahan Permenkes No 66 Tahun 2016 yaitu penyelenggaraan K3RS, dikarenakan pada saat sekarang dan masa akan datang RS lebih memfokuskan pencegahan , "Patient Safety" daripada pengobatan penyakit, dan RS juga harus memperhatikan lingkungan sekitar rumah sakit baik lingkungan fisik bangunan maupun pengunjung, keluarga dan staf. Secara administratif, rumah sakit dibawah pengawasan kementerian kesehatan melalui dinas kesehatan setempat. Secara hukum administratif, rumah sakit memberikan laporan secara berkala tentang K3RS, dari laporan tersebut dapat timbul peristiwa hukum dan akibat hukum serta diketahui ada dan tidak timbul perbuatan melawan hukum.

Terjadi banjir, kebakaran, longsor, kesalahan pemberian obat, lambat penangganan pasien, serta kecelakaan kerja di rumah sakit yang bukan merupakan malpraktik adalah akibat lemah pelaksanaan K3RS dan dapat menimbulkan akibat hukum berupa kerugian pada pasien, pengunjung serta keluarga pasien; dan lingkungan sekitarnya. Hal ini berarti salah satu contoh tidak melaksnakan Pasal 7 Permenkes No 66 Tahun 2016.
B. Sanksi Administrasi Yang Dapat Diberikan Kepada Rumah Sakit Yang Tidak Melaksanakan Permenkes No 66 Tahun 2016




\section{Tentang Keselamatan Dan Kesehatan Kerja Rumah Sakit}

Menurut Willy D.S Voll dalam buku Dasar-Dasar Ilmu Hukum Administrasi Negara tentang kebijakan administrasi dalam negara modern; demokrasi mengandung arti bahwa kebijakan diambil demi kepentingan dan keuntungan rakyat sebagai pemegang kedaulatan (pelaku negara). Persoalan terjadi apabila ada satu rakyat atau beberapa rakyat atau sekelompok rakyat yang dirugikan oleh kebijakan administrasi. Kelompok masyarakat yang dirugikan disini adalah pasien, pengunjung pasien, keluarga pasien dan yang bekerja di rumah sakit; dan lingkungan sekitar rumah sakit. Hal ini berbenturan dengan Pasal 1 Permenkes No 66 Tahun 2016.

Pejabat administrasi (bestuur) selaku pelaksana kebijakan politik negara mempunyai wewenang sebagaimana diperintahkan undang - undang, berfungsi memimpin masyarakat, mengendalikan pemerintahan, memberi petunjuk, menghimpun aspirasi, menggerakkan potensi, memberi arah, mengkoordinasikan kegiatan, membuka kesempatan, memberi kesempatan, memberi kemudahan, mengawasi, menilai, mendukung, membina, melayani, mendorong dan melindungi masyarakat. Dalam hal ini pejabat administrasi adalah Gubernur, Walikota, Bupati.

Dalam rangka mensejahterakan masyarakat, terjadi hubungan hukum (rechtsbetrekking) yang erat antara pemerintah dengan rakyatnya. Dengan perkataan lain, pemerintah mempunyai kewajiban untuk memberikan pelayanan kepada masyarakat (public service). Perbuatan aparat pemerintah yang dilaksanakan berdasarkan peraturan perundang-undangan maupun diskresi jika tidak terkendali dengan baik, maka akan mudah terjadi perbuatan yang tercela, yang tendensinya menimbulkan kerugian pada pihak tertentu. Perbuatan pemerintah yang tercela ini dalam Hukum Tata Administrasi Negara sering disebut perbuatan penguasa yang sewenang-wenang (willekeur). Perbuatan yang sewenang-wenang ini. frekuensinya banyak terjadi dalam penyelenggaraan pemerintahan yang bersifat bebas (vrij bestuur). Dalam penyelenggaraan pemerintahan yang bersifat mengikat (gebonden bestuur) perbuatan tersebut jarang terjadi. ${ }^{14}$ Perbuatan ini digambarkan sebagai ketidakpedulian terhadap K3RS dengan tidak melaksanakan Permenkes tentang K3RS.

Kekuasaan penguasa tidak pernah mutlak, tetapi selalu terbatas, karena dalam mengandalkan perjanjian dengan seseorang atau sekelompok orang, individu - individu tidak menyerahkan seluruh hak alami mereka. Ada hak alamiah mereka yang merupakan hak - hak asasi yang tidak dapat dipisahkan atau dilepas, juga oleh individu tersebut. Penguasa yang diserahi tugas mengatur hidup individu dalam ikatan kenegaraan harus menghormati hak asasi tersebut.

Hubungan antara masyarakat dengan hukum, merupakan satu kesatuan yang tidak dapat dipisahkan. Ini sesuai dengan ungkapan ubi societas ibi ius (di mana ada masyarakat disitu ada hukum). Dapat ditegaskan bahwa hukum memiliki fungsi untuk mengatur kehidupan masyarakat dalam menjalankan aktivitasnya, sehingga melalui pengaturan itu bisa terwujud satu masyarakat yang sejahtera sesuai dengan yang diamanatkan dari tujuan negara Indonesia yang tercantum dalam

14 Muchsan, Sistem Pengawasan Terhadap Perbuatan Aparat Pemerintah Dan Peradilan Tata Usaha Negara Di Indonesia. Liberty, Yogyakarta. 1992, hlm.14. 
Pembukaan UUD 1945. Beranjak dari pemikiran tersebut, keberadaan hukum sangat diperlukan dalam kehidupan masyarakat.

Jika kebijakan administrasi itu termasuk kategori perbuatan melanggar hukum, maka ganti rugi yang wajib dibayar oleh administrasi yang berkaitan dengan pemerintah negara berdasarkan ganti rugi karena perbuatan yang melanggar hukum dengan segala konsekuensi administrasinya terhadap penjamin-administrator pelaku atau pengambil kebijakan. Sebaliknya jika kebijakan itu adalah sah, berdasarkan pada hukum, maka ganti rugi yang wajib dibayar adalah " ganti rugi karena perbuatan yang sah." 15 Dalam hal ini ganti rugi dapat diberikan apabila tidak terjadi kerugian berupa kehilangan nyawa. Bila terjadi maka terjadi pelanggaran terhadap hukum pidana. Tidak setiap kerugian dapat diganti rugi misalnya terjadi kecacatan atau kehilangan pada organ manusia akibat kelalaian pelaksanaan K3RS.

Pemerintah atau administrasi negara merupakan subyek hukum dan pendukung hak-hak dan kewajiban-kewajiban. Sebagai subyek hukum, pemerintah melakukan berbagai tindakan baik tindakan nyata maupun tindakan hukum. Tindakan nyata adalah tindakan yang tidak ada relevansinya dengan hukum dan oleh karenanya tidak menimbulkan akibat hukum. Sedangkan tindakan hukum adalah tindakan yang berdasar sifatnya dapat menimbulkan akibat hukum. Istilah tindakan hukum ini bermula berasal dari ajaran hukum perdata, yang kemudian digunakan dalam hukum administrasi negara sehingga dikenal dengan istilah tindakan hukum administrasi. ${ }^{16}$

${ }^{15}$ Willy D.S Voll, Op.cit.,hlm.147.

${ }^{16}$ Juniarso Ridwan, dan Achmad Sodik Sudrajat, Hukum Administrasi Negara Dan Kebijakan Pelayanan Public, PT Nuansa Cendekia, Bandung ,2014, hlm.18.
Kerugian yang timbul pada obyek hukum yaitu pasien, pengunjung, keluarga pasien, dan pekerja rumah sakit dapat berhubungan dengan hukum perdata berupa ganti rugi dan dapat berhubungan dengan hukum publik berupa hukum administrasi dan hukum pidana. Hukum administrasi yang diberikan berupa mutasi pegawai, atau hukuman disiplin kategori berat, sedang, ringan. Hal ini dapat dilihat pada Peraturan Pemerintah Nomor 11 Tahun 2017 tentang Manajemen Pegawai Negeri Sipil dan Peraturan Pemerintah Nomor 53 Tahun 2010 tentang Disiplin Pegawai Negeri Sipil.

Pemerintah atau administrasi negara adalah subyek hukum yang mewakili dua institusi yaitu jabatan pemerintahan dan badan hukum. Karena mewakili dua institusi, dikenal ada dua tindakan hukum yaitu tindakan hukum publik dan tindakan hukum privat.

Secara teoritis, cara untuk menentukan apakah tindakan pemerintahan itu diatur oleh hukum privat atau hukum publik adalah dengan melihat kedudukan pemerintah dalam menjalankan tindakan tersebut. Jika pemerintah bertindak dalam kedudukannya sebagai pemerintah, hanya hukum publiklah yang berlaku. Jika pemerintah bertindak tidak dalam kapasitas sebagai pemerintah, hukum privatlah yang berlaku. Dengan kata lain, ketika pemerintah dalam hal ini diwakilkan wewenang berupa atribusi atau delegasi oleh Gubernur, Walikota, Bupati dan Direktur RS Negara maupun Swasta terlibat dalam pergaulan publik maka hukum publik yang berlaku. Contoh hukum publik adalah adanya banjir dan kebakaran di rumah sakit, pemberian makanan yang membuat penyakit, lantai yang licin, peralatan yang tidak steril, dan adanya pelayanan rumah sakit yang keluar dari ketentuan jaminan kesehatan negara yang merupakan tanggung jawab terhadap keselamatan dan kesehatan kerja. 
Beberapa tahun terakhir ini sering timbul gugatan dari pasien yang merasa dirugikan, untuk menuntut ganti rugi akibat kesalahan atau kelalaian yang dilakukan oleh dokter atau tenaga kesehatan atau karyawan rumah sakit dalam melaksanakan pekerjaannya. Berbagai kasus telah disidangkan di pengadilan dan mendapat sorotan dari profesi kalangan kesehatan dan profesi hukum serta masyarakat umum. Keadaan seperti ini menunjukkan suatu gejala, bahwa rumah sakit mulai dilanda krisis etika dan kepercayaan, bahkan juga krisis keterampilan medik yang tidak dapat diselesaikan dengan kode etik kedokteran semata-mata, melainkan harus diselesaikan dengan cara yang lebih luas lagi yaitu harus diselesaikan melalui jalur hukum.

Munculnya permasalahan seperti itu merupakan indikasi bahwa kesadaran hukum masyarakat semakin meningkat. Peningkatan kesadaran masyarakat akan aturan hukum, semakin mengetahui mereka akan hak dan kewajibannya dan semakin luas pula suara-suara yang menuntut agar hukum memainkan peranannya di bidang kesehatan. Masyarakat telah mengetahui bagaimana harus bertindak sesuai dengan hak dan kepentingannya apabila mereka menderita kerugian sebagai akibat dari kesalahan atau kelalaian yang terjadi akibat pelayanan di rumah sakit.

Dampak dari akibat hukum yang timbul, selain merusak atau mengurangi kepercayaan masyarakat terhadap rumah sakit, profesi kedokteran, pembangunan kesehatan seperti jaminan kesehatan negara juga menimbulkan kerugian pada pasien. Untuk itu dalam memahami ada atau tidak adanya kesalahan atau kelalaian tersebut, terlebih dahulu kesalahan atau kelalaian pelaksanaan profesi harus diletakkan berhadapan dengan kewajiban profesi. Profesi yang ada di rumah sakit terdiri dari beragam profesi mulai dari pintu masuk rumah sakit sampai pintu keluar rumah sakit, dengan kata lain aturan masuk dan keluar rumah sakit sudah mengikuti kaedah K3RS.

Peraturan Menteri Kesehatan Republik Indonesia Nomor 66 Tahun 2016 Tentang Keselamatan Dan Kesehatan Kerja Rumah Sakit adalah produk peraturan yang mengatur tentang Keselamatan dan Kesehatan Kerja di Rumah Sakit agar terselenggara secara optimal, efektif, efisien dan kesinambungan. Hal ini tercantum dalam pada Pasal 2 dalam peraturan tersebut.

Sebelum PERMENKES terbit telah ada Keputusan Menteri Kesehatan Nomor 432 Tahun 2007 Tentang Pedoman Manajemen Kesehatan dan Keselamatan Kerja di Rumah Sakit. Keputusan ini sebagai pedoman rumah sakit untuk akreditasi rumah sakit yang mana beberapa point pelaksanaan akreditasi tersurat pelaksanaan keselamatan dan kesehatan kerja.

Didalam Peraturan Menteri Kesehatan No 66 Tahun 2016 Tentang Keselamatan dan Kesehatan Kerja Rumah Sakit terdiri dari sebelas bab, Setiap bab menjelaskan pelaksanaan tentang Keselamatan dan Kesehatan Kerja. Bab III menjelaskan standar keselamatan dan kesehatan kerja rumah sakit dan Bab VIII menjelaskan penilaian keselamatan dan kesehatan kerja rumah sakit,

Didalam Peraturan Menteri Kesehatan tersebut tidak tersurat penjelasan secara detail mengenai sanksi yang diberikan kepada rumah sakit sehubungan pelaksanaan keselamatan dan kesehatan kerja rumah sakit. Sanksi yang diberikan kepada rumah sakit ada dituangkan pada Undang Undang Nomor 44 Tahun 2009 Tentang Rumah Sakit.

Kurang responsif, kurang inovatif, kurang accessible, kurang koordinasi, birokratis, dan kurang mau mendengar keluhan, saran, dan aspirasi masyarakat 
merupakan kelemahan yang terjadi pada rumah sakit sehingga dapat menimbulkan peristiwa hukum. Hal ini dapat dilihat pada lampiran yang mengambarkan adanya banjir lebih dari sekali dalam kurun waktu kurang dari 6 (enam) bulan dan melakukan evakuasi pasien. Apabila K3RS dilaksanakan dengan baik dan benar maka hal tersebut tidak akan terjadi karena sudah diamanahkan dalam Permenkes Nomor 66 Tahun 2016 Tentang K3RS pasal 7.

Sanksi yang diberikan kepada rumah sakit yang menimbulkan kerugian, selain mengandung tanggung gugat perdata dan pertanggungjawaban pidana, juga mengandung pertanggungjawaban di bidang hukum administrasi. Sanksi administratif dapat dilihat pula pada Pasal 29 ayat (4) Permenkes No 66 Tahun 2016 tentang K3RS yang berbunyi : "Dalam rangka pembinaan dan pengawasan K3RS, menteri, kepala dinas kesehatan provinsi, kepala dinas kesehatan kabupaten/kota dapat memberikan sanksi administratif berupa teguran lisan atau teguran tertulis kepada Rumah Sakit yang tidak menyelenggarakan K3RS"; dibandingkan bunyi Pasal 29 ayat (2) UU No 44 Tahun 2009 tentang Rumah Sakit mengenai pelanggaran atas kewajiban sistem pencegahan kecelakaan dan penanggulangan bencana, rumah sakit dikenakan sanksi admisnistratif berupa teguran, teguran tertulis atau denda dan pencabutan izin Rumah Sakit. Ketidaktegas sanksi yang terbit pada Permenkes tersebut dapat membuat tidak optimal penyelenggaraan K3RS.

Sanksi administrasi dimaksudkan agar perbuatan pelanggaran itu dihentikan. Sifat sanksi adalah "reparatoir" artinya memulihkan pada keadaan semula. Pemberian sanksi diikuti pengawasan yang ketat oleh menteri, kepala dinas kesehatan dapat membuat penyelenggara K3RS menjadi berkesinambungan.
Tujuan hukuman administrasi yang dijatuhkan terhadap rumah sakit yang melakukan kesalahan, adalah untuk memperbaiki dan mendidik rumah sakit yang berangkutan. Oleh karena itu, jika hukuman disiplin dalam bidang pelayanan kesehatan diterapkan, maka dengan sendirinya rasa tanggung jawab yang mendalam akan mendorong mereka untuk melakukan kewajiban profesi dan mematuhi ketentuan-ketentuan hukuman yang telah digariskan.

Menghadapi problem yang demikian ini maka unsur profesionalisme merupakan hal yang mutlak. Karena profesionalisme berkaitan erat dengan pelayanan. Unsur lain yang mengikat dalam profesionalisme adalah unsur nasionalisme dan unsur persatuan kerja dalam tim. Hal tersebut diatas sudah terangkum dalam Keselamatan dan Kesehatan Kerja.

Setelah penjelasan diatas diberikan maka penulis mempunyai analisis bahwa sanksi administrasi yang diberikan diawali dengan hukuman disiplin pada pegawai sesuai dengan kesalahan yang dilakukan, kemudian teguran lisan kepada pimpinan / direktur rumah sakit, dilanjutkan teguran tertulis kepada rumah sakit dari instansi diatasnya sampai dilakukan pembekuan ijin operasional dari rumah sakit tersebut. Apabila diperlukan maka dapat dilanjutkan pada peradilan perdata maupun peradilan pidana.

Sanksi dapat diberikan disesuaikan dengan perbuatannya dan sanksi diatur dalam Undang-Undang Rumah Sakit, Peraturan Pemerintah tentang disiplin pegawai, dan Permenkes tentang K3RS serta peraturan lainnya yang terkait. 


\section{KESIMPULAN DAN SARAN}

\section{Kesimpulan}

Bentuk

Tanggung Jawab

Administrasi Rumah Sakit Terhadap Keselamatan dan Kesehatan Kerja Rumah Sakit adalah melaksanakan kewajiban berkesinambungan amanah Peraturan Menteri Kesehatan Nomor 66 Tahun 2016 Tentang Keselamatan dan Kesehatan Kerja Rumah Sakit sesuai dengan arahan dan standar yang diberikan. Pelaksanaan tersebut dibawah pengawasan Dinas Kesehatan dan Menteri Kesehatan.

Sanksi dapat diberikan kepada rumah sakit berupa sanksi hukum administrasi yang dimulai dari teguran lisan sampai dengan pencabutan ijin operasional rumah sakit, kemudian dapat dilanjutkan dengan diberikan sanksi hukum perdata dan sanksi hukum pidana sesuai dengan tindakan melawan hukum yang dilakukan. Dalam Peraturan Menteri Kesehatan Nomor 66 Tahun 2016 tersurat sanksi administratif.

\section{DAFTAR PUSTAKA}

\section{Buku:}

Asyhandie, Zaeni. Pengantar Ilmu Hukum, PT RajaGrafindo Persada, ed ke - 2, Jakarta, 2014.

Arsyad, Jawade Hafidz, Korupsi dalam Perseptif HAN, Sinar Grafika, Jakarta, 2015.

Azwar, Asrul. Pengantar Administrasi Kesehatan, Ed 3, Bina Rupa Aksara, Jakarta.

Bisri, Ilhami, Sistim Hukum Indonesia Prinsip-Prinsip dan Implementasi Hukum Indonesia, PT Raja Grafindo Persada, Cet Ketujuh, Depok, 2012.

\section{Saran}

Mensosialisasikan Tanggung Jawab Administrasi Rumah Sakit dengan melakukan koordinasi dengan pemerintahan daerah dan dinas kesehatan setempat yang dilakukan berkesinambungan dan terintegrasi dengan tim K3RS berupa Instalasi, Komite, Pokja dan lainnya; yang disertakan pengawasan dan monitoring dari institusi profesional yang independent.

Diberikan sanksi yang tegas kepada Rumah Sakit dan atau Pimpinan dan atau Pemilik Rumah Sakit sesuai dengan perbuatan yang dilakukan. Sanksi tahap pertama berupa sanksi hukum administrasi berupa teguran lisan, teguran tertulis sampai pembekuan operasional rumah sakit. Apabila dimungkinkan maka sanksi dapat berupa sanksi hukum perdata dan sanksi hukum pidana; penghargaan juga perlu diberikan apabila tercapai pelaksanaan K3RS sesuai dengan Permenkes Nomor 66 Tahun 2016.

Departemen Kesehatan R.I, Panduan Nasional Keselamatan Pasien Rumah Sakit, Bhakti Husada, 2006.

Djamali, R.Abdoel, Pengantar Hukum Indonesia, PT Raja Grafindo Persada, Jakarta, 2013.

Erwin, Muhamad, Filsafat Hukum, Refleksi Kritis terhadap Hukum, PT. Raja Grafindo Persada, Jakarta, 2011.

Erwin Muhamad, Firman F Busroh, Pengantar Ilmu Hukum, PT Refika Aditama, Bandung, 2012.

Fuady, Munir, Perbuatan Melawan Hukum Pendekatan Kontemporer, PT Citra Aditya Bakti, Banung, Ed IV, 2013.

\section{Saran}


Hadjon, Philipus M. et al, Pengantar Hukum Administrasi Indonesia, Gadjah Mada University Press, Yogyakarta, 2015.

Hart H.L.A, Konsep Hukum, Nusa Media, Bandung, 2016.

HR, Ridwan, Hukum Administrasi Negara, Raja Grafindo Persada, Jakarta, 2013.

HS, Salim dan Erlies Septiana Nurbani, Penerapan Teori Hukum Pada Penelitian Tesis dan Disertasi, PT. Raja Grafindo Persada, Jakarta, 2013. Lebih jauh lihat, Lawrence M. Friedman, The Legal System: A Social Science Perspective, Russel Sage Foundation, New York, 1975.

Ishaq, Dasar-Dasar Ilmu Hukum, Sinar Grafika, Jakarta, 2016

Kamus Besar Bahasa Indonesia, Ed 2, Balai Pustaka, Jakarta, 1994.

Kelsen, Hans, Teori Hukum Murni DasarDasar Ilmu Hukum Normatif, Nusa Media, Bandung, 2016.

, Teori Umum Tentang Hukum Dan Negara, Nusa Media, Bandung, 2016.

Marzuki, Peter Mahmud, Pengantur Ilmu Hukum, cetakan ke-3, Penerbit Kencana Prenada Media Group, Jakarta, 2009.

Machmudin, Dudu Duswara, Pengantar Ilmu Hukum Sebuah Sketsa, PT Refika Aditama, Bandung, 2013.

Mertokusumo, Sudikno, Mengenal Hukum Suatu Pengantar, Cahaya Atma Pustaka, Yogyakarta, 2016.

Mustafa, Bachsan, Sistem Hukum Indonesia Terpadu, PT Citra AdityaBakti, Bandung, 2003.

Nasution, Bahder Johan, Hukum Kesehatan Pertanggungjawaban Dokter, PT Rineka Cipta, Jakarta, 2013.

P.K.Suma'mur, Higiene Perusahaan dan

Kesehatan Kerja (Hiperkes), Sagung Seto, Jakarta, 2009.
Raharjo, Satjipto, Ilmu Hukum, Cet Ketujuh, PT.Citra Aditya Bakti, Bandung, 2012.

Ramli, Soehatman, Sistem Manajemen Keselamatan dan Kesehatan Kerja OHSAS 18001, Dian Rakyat, Jakarta, 2010.

Ridwan, Juniarso, Achmad Sodik Sudrajat, Hukum Administrasi Negara dan Kebijakan Layanan Publik, Nuansa Cendekia, Bandung, 2014.

Situmorang, Chaidir, Mengikuti Prosedur Menjaga Kesehatan Dan Keselamatan Kerja, Bakti Husada, Jakarta, 2003.

Ta'adi, Hukum Kesehatan: Sanksi \& Motivasi Bagi Perawat, Ed 2, Buku Kedokteran EGC, Jakarta, 2013.

Voll, Willy D.S., Dasar-Dasar Ilmu Hukum Administrasi Negara, Sinar Grafika, Jakarta, 2013.

Warassih, Esmi, Pranata Hukum, Sebuah Telaah Sosiologi, Semarang. Penerbit Universitas Diponegoro. 2011.

Wiratno, Pengantar Hukum Administrasi Negara, Penerbit Universitas Trisakti, Jakaarta, 2011.

\section{Peraturan Perundang-undangan:}

Undang-Undang Dasar Republik Indonesia Tahun 1945. Amandemen IV.

Undang-Undang Republik Indonesia Nomor 1 Tahun 1970 Tentang Keselamatan Kerja.

Undang-Undang Republik Indonesia Nomor 28 Tahun 1999 Tentang Penyelenggara Negara Yang Bersih dan Bebas dari Korupsi, Kolusi dan Nepotisme.

Undang-Undang Republik Indonesia Nomor 36 Tahun 2009 Tentang Kesehatan. 
Undang-Undang Republik Indonesia

Nomor 44 Tahun 2009 Tentang

Rumah Sakit.

Peraturan Pemerintah Nomor 53 Tahun 2010 Tentang Disiplin Pegawai Negeri Sipil.

Peraturan Pemerintah Nomor 11 Tahun 2017 Tentang Manajemen Pegawai Negeri Sipil.

Peraturan Menteri Kesehatan Nomor 66 Tahun 2016 Tentang Keselamatan dan Kesehatan Kerja Rumah Sakit.

Keputusan Menteri Kesehatan Nomor 432

Tahun 2007 Tentang Pedoman

Manajemen Kesehatan dan

Keselamatan Kerja di Rumah Sakit.

Tesis:

Liza Salawati, Hubungan Prilaku, Manajemen Keselamatan dan

Kesehatan Kerja dengan

Terjadinya Kecelakaan Kerja di

Laboratorium Patologi Klinik

Rumah Sakit Umum DR Zainoel

Abidin Banda Aceh tahun

2009, Tesis.Universitas Sumatera

Utara Medan, Medan, 2009.

Jurnal:

Martina Parubak, Studi Kecelakaan Kerja

Pada Petugas RS Elim Rantepao dan RSUD Lakipadada Makale Kabupaten Tana Toraja, Artikel Dalam Jurnal Media Kesehatan Masyarakat Indonesia, Volume 5 Nomor 4, Oktober 2009. 